PENERAPAN MODEL PEMBELAJARAN FLIPPED CLASSROOM TIPE PEER INSTRUCTION FLIPPED UNTUK MENINGKATKAN KEMAMPUAN PEMECAHAN MASALAH MATEMATIS SISWA PRA SEJAHTERA

\title{
APPLICATION OF FLIPPED CLASSROOM LEARNING MODELS WITH PEER INSTRUCTION FLIPPED TYPE TO IMPROVE THE MATHEMATICAL PROBLEMS SOLVING ABILITY OF PRE- PROSPEROUS STUDENTS
}

\author{
Angra Meta Ruswana ${ }^{1)}$ \\ ${ }^{1}$ FKIP Universitas Galuh, Ciamis \\ *E-mail : angra.meta @gmail.com
}

\begin{abstract}
ABSTRAK
Penelitian ini dilatarbelakangi oleh masih rendahnya kemampuan pemecahan masalah matematis. Tujuan dari penelitian ini untuk menelaah dan mendeskripsikan perbedaan peningkatan kemampuan pemecahan masalah matematis siswa antara siswa pra sejahtera yang menggunakan model pembelajaran flipped classroom tipe peer instruction flipped dengan siswa pra sejahtera yang menggunakan pembelajaran konvensional. Penelitian dilaksanakan di SMK Taruna Bangsa Ciamis pada kelas XI. Metode penelitian yang digunakan adalah Quasi-Experiment. Untuk mendapatkan data hasil penelitian digunakan instrumen berupa tes kemampuan pemecahan masalah matematis. Analisis data dilakukan terhadap gain ternormalisasi kedua kelompok sampel dengan menggunakan uji perbedaan gain ternormalisasi. Hasil penelitian menunjukkan bahwa terdapat perbedaan peningkatan kemampuan pemecahan masalah matematis siswa antara siswa pra sejahtera yang menggunakan model pembelajaran flipped classroom tipe peer instruction flipped dengan siswa pra sejahtera yang menggunakan pembelajaran menggunakan konvensional.
\end{abstract}

Kata kunci: Flipped Classroom tipe Peer Instruction Flipped, Kemampuan Pemecahan Masalah Matematis

\section{ABSTRACT}

This research was motivated by the low mathematical problem solving abilities. The aims of this research are to examine and describe the differences between preprosperous students who used flipped classroom learning models with peer instruction flipped type and pre-prosperous students who used conventional learning in the improvement of students' mathematical problem solving abilities. This research was conducted in class XI of SMK Taruna Bangsa, Ciamis. The research used Quasi-Experiment method by using instrument in the form of mathematical problem solving ability test to obtain the research data. Data analysis was conducted on normalized gain of two sample groups by using the normalized gain difference test. The result showed there were the differences between preprosporous students who used flipped classroom learning model with peer instruction flipped type and students who used conventional learning in the improvement of students' mathematical problem solving abilities.

Keyword : Flipped Classroom Learning Models with Peer Instruction Flipped Type, Mathematical Problem Solving Ability 


\section{PENDAHULUAN}

Pendidikan merupakan salah satu kunci penanggulangan kemiskinan dalam jangka menengah dan jangka panjang. Namun, sampai dengan saat ini masih banyak orang miskin yang memiliki keterbatasan akses untuk memperoleh pendidikan bermutu, hal ini disebabkan antara lain karena mahalnya biaya pendidikan. Disisi lain, Undang-Undang Nomor 20 Tahun 2003 tentang Sistem Pendidikan Nasional mengamanatkan bahwa setiap warga negara berusia 7-15 tahun wajib mengikuti pendidikan dasar, yang dikenal dengan Program Wajib Belajar Pendidikan Dasar Sembilan Tahun. Pada pasal 34 ayat 2 tertera bahwa pemerintah dan pemerintah daerah menjamin terselenggaranya wajib belajar minimal jenjang pendidikan dasar tanpa memungut biaya, sedangkan dalam ayat 3 menyebutkan, bahwa wajib belajar merupakan tanggung jawab negara yang diselenggarakan oleh lembaga pendidikan pemerintah, pemerintah daerah, dan masyarakat.

Keberhasilan pendidikan merupakan tanggungjawab bersama antara keluarga, anggota masyarakat, dan pemerintah. Pemerintah dan masyarakat menyediakan tempat belajar yaitu sekolah. Sekolah menampung siswa-siswinya dari berbagai macam latar belakang dan kondisi yang berbeda. Pada umumnya anak-anak yang berasal dari keluarga menengah ke atas mendapatkan pengarahan dan bimbingan yang cukup baik dari orang tua mereka, sedangkan anak-anak yang berasal dari keluarga ekonomi rendah kurang mendapat bimbingan dan perhatian yang cukup dari orang tua mereka karena orang tua mereka lebih memusatkan perhatiannya pada bagaimana untuk memenuhi kebutuhan seharihari mereka.

Salah satu disiplin ilmu yang mempunyai peranan penting dalam pendidikan dan dalam kehidupan sehari-hari adalah matematika. Matematika perlu dipahami oleh semua lapisan masyarakat terutama siswa sekolah formal, sehingga matematika merupakan salah satu ilmu yang diajarkan dari jenjang Sekolah Dasar (SD) hingga Perguruan Tinggi (PT). Dalam Standar Isi (SI) kurikulum 2006 dinyatakan bahwa tujuan mata pelajaran matematika di sekolah adalah agar siswa mampu memahami konsep matematika, menggunakan penalaran, memecahkan masalah, mengkomunikasikan gagasan, memiliki sikap menghargai kegunaan matematika dalam kehidupan (Wardhani, 2010). Dari penjelasan tersebut memecahkan masalah merupakan hal yang penting dan harus dimiliki seseorang dalam mempelajari matematika.

Kemampuan pemecahan masalah sangat penting dimiliki setiap orang. Bukan hanya karena sebagian besar kehidupan manusia akan berhadapan dengan masalah-masalah yang perlu dicari penyelesaiannya, tetapi pemecahan masalah juga dapat meningkatkan daya analitis dan dapat membantu untuk menyelesaian permasalahan-permasalahan pada berbagai situasi yang lain. Hal ini sejalan dengan yang diungkapkan Cooney (Hudojo, 2003) bahwa dengan mengajarkan siswa untuk menyelesaikan masalah akan memungkinkan siswa tersebut menjadi lebih analitis mengambil keputusan dalam kehidupan. 
Keberagaman latar belakang pendidikan pada siswa SMK Taruna Bangsa Ciamis menjadi salah satu faktor penghambat siswa dalam mengikuti pembelajaran Matematika. Pada umumnya siswa yang kesulitan belajar matematika saat di SD dan SMP berdampak pada rendahnya sikap dan kemampuan pemecahan matematis pada pembelajaran Matematika, sehingga masih memungkinkan adanya anggapan negatif siswa terhadap matematika.

Berdasarkan fakta yang telah dikemukakan, hal ini menunjukkan bahwa kemampuan pemecahan matematis siswa masih belum maksimal. Jadi salah satu permasalahan yang dihadapi saat ini adalah rendahnya kemampuan pemecahan masalah matematis siswa. Untuk menyelesaikan masalah ini, maka perlu mencari berbagai alternatif solusi yang baik agar kualitas pembelajaran matematika dapat diperbaiki, sehingga melalui kemungkinan-kemungkinan solusi yang dikembangkan diharapkan dapat membantu meningkatkan kemampuan pemecahan masalah matematis. Salah satu model pembelajaran yang berpotensi mampu untuk meningkatkan kemampuan pemecahan masalah matematik adalah model flipped classroom tipe peer instruction flipped.

Pada model pembelajaran flipped classroom tipe peer instruction flipped, model tersebut dapat melatih siswa untuk lebih aktif dalam pembelajaran karena siswa akan mengkontruksi konsep yang dipelajari bersama temannya melalui kegiatan diskusi dan ConcepTest yang diberikan oleh guru. Keunikan model pembelajaran flipped classroom ini adalah dalam pembelajaran guru menggunakan bantuan perangkat multimedia dan teknologi yaitu video untuk bekal pengetahuan awal siswa sebelum pembelajaran kelas berlangsung.

Model Flipped Classroom dimaksudkan agar pembelajaran yang dilakukan di kelas lebih efektif. Bergman dan Sams (2012) membandingkan model pembelajaran konvensional dengan model pembelajaran Flipped Classroom. Pada model pembelajaran konvensional, siswa datang ke kelas dengan rasa bingung dengan pekerjaan rumah yang diberikan dipertemuan sebelumnya. Biasanya guru menghabiskan 25 menit pertama untuk membahas pekerjaan rumah yang siswa belum pahami. Guru memberikan materi baru selama 30 sampai 45 menit dan sisanya dihabiskan di kelas dengan latihan secara mandiri atau kelompok. Akan tetapi pada model pembelajaran flipped classroom, waktu diatur dengan sepenuhnya. Di awal pembelajaran siswa perlu menanyakan pertanyaan tentang materi yang telah dikirim melalui video, jadi guru umumnya menjawab pertanyaan tersebut selama menit pertama di kelas. Hal ini membiarkan guru menyelesaikan miskonsepsi sebelum mereka berlatih dan melakukan penyelesaian dalam penerapan konsep. Waktu sisa digunakan lebih luas untuk aktivitas sendiri untuk penyelesaian masalah secara langsung.

Flipped classroom ini merupakan pembalikan pembelajaran kelas tradisional dengan memanfaatkan internet, di mana jika dalam kelas tradisional pembelajaran materi dilakukan di kelas dan tugas terkait materi pembelajaran dikerjakan siswa di rumah, sedangkan dalam pembelajaran flipped classroom yang terjadi adalah siswa mempelajari materi pembelajaran di rumah. Hal ini juga dijelaskan dalam Carl Reidsema, dkk (2017) yaitu

"In the flipped classroom, students are required to engange in or complete some form of preliminary learning online in preparation for a structurally 
aligned learning activity on campus with their instructors and peers. The structural alignment between these two activities is an important distinction for those who may think that simply uploading their lecture recordings will suffice. In flipped mode, students will be meeting a topic for the first time online usually via short and to the point videos, rather than through attending a lecture as has been tradionally the case. This sudden change in direction (often referred to as "reverse teaching") can be quite confronting to students whose conceptions of universuty teaching are that new material should be presented by a professor in a lecture that they have paid good money to attend".

Namun ada 4 hal yang perlu perhatikan sebelum melaksanakan flipped classroom menurut Clarice M. Morgan dan Carl A. Young (2015), seperti: apakah desain flipped classroom yang dibuat digunakan untuk siswa; apakah flipped classroom yang dibuat untuk lebih dari satu kali pertemuan; apakah sudah memilih konten yang cocok untuk digunakan pada flipped classroom; dapatkah siswa mendemonstrasikan apa yang telah mereka lihat dan pelajari dari konten yang disediakan; apakah dalam pembelajaran flipped classroom juga dilakukan pendekatan proaktif dalam manajemen kelas. Adapun 10 alasan untuk melakukan flipped classroom menurut Kathleen P. Fulton (2012), seperti: siswa memahami materi dengan langkah mereka masing-masing; mengerjakan "latihan" di kelas membuat guru lebih mengetahui kemampuan pemahaman siswa baik kesulitan yang dialami maupun gaya belajar siswa; guru dapat menyesuaikan dan memperbarui kurikulum serta menyediakannya bagi siswa selama 24 jam setiap harinya; siswa dapat mengakses pembelajaran beberapa guru dengan keahliannya masing-masing; perkembangan flipped classroom yang dilakukan oleh guru dilihat secara profesional dengan saling melihat video antar guru dan pembelajarannya; waktu di kelas dapat digunakan secara lebih efektif dan kreatif; orang tua dapat melihat soal latihan; pencapaian siswa yang meningkat, sehingga menarik dan menjanjikan untuk matematika ke level yang lebih tinggi; mempelajari teori yang mendukung pada pendekatanpendekatan yang baru; dan manfaat dari menggunakan tehknologi adalah fleksibel dan sesuai untuk pembelajaran abad 21.

John Gunyou (2015) yang membahas tentang desain pembelajaran flipped classroom yang dibuatnya yaitu dengan siklus sebagai berikut:

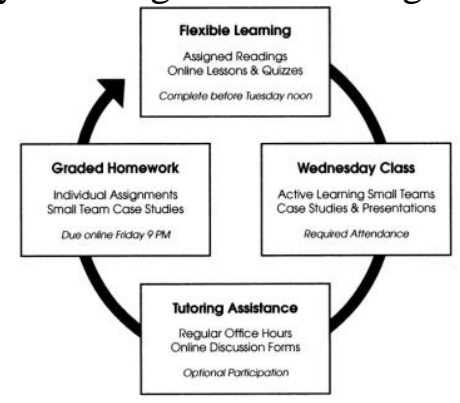

Gambar 1. Siklus Flipped Classroom 
Menurut Steele (2016), terdapat beberapa tipe model pembelajaran Flipped classroom yaitu :

a. $\quad$ Traditional Flipped merupakan model pembelajaran flipped classroom yang paling sederhana. Biasanya digunakan oleh guru pemula yang baru menerapkan model flipped classroom. Langkah pembelajarannya adalah siswa menonton video pembelajaran dirumah, lalu ketika dikelas melakukan kegiatan dan mengerjakan tugas yang diberikan secara kelompok. Lalu diakhir pembelajaran dilakukan kuis secara individu atau berpasangan.

b. Mastery Flipped merupakan perkembangan dari Traditional Flipped. Tahapan pembelajarannya hampir serupa dengan pembelajaran Traditional Flipped, hanya saja pada awal pembelajaran model ini diberikan pengulangan pembelajaran pada pertemuan sebelumnya.

c. Peer Instruction Flipped adalah model pembelajaran dimana siswa mempelajari materi dasar sebelum memulai kelas melalui video. Ketika dikelas siswa menjawab pertanyaan konseptual secara individu, siswa diberikan kesempatan untuk saling beradu pendapat terhadap soal yang diberikan untuk meyakinkan jawabannya kepada temannya dan diakhir diberikan tes pemahaman.

d. Problem Based Learning Flipped adalah siswa diberikan video yang memberikan petunjuk untuk menyelesaikan masalah yang akan muncul ketika di kelas. Pada model ini siswa bekerja dengan bantuan guru. Ketika di kelas siswa melakukan eksperimentasi dan evaluasi.

Model pembelajaran peer instruction flipped merupakan penerapan model pembelajaran Flipped Classroom dengan pembelajaran peer instruction. Peer Instruction dipelopori oleh Prof. Eric Mazur pada tahun 1997. Pembelajaran ini menekankan partisipasi aktif siswa dalam kelas melalui kegiatan diskusi tentang pertanyaan pemahaman konsep mendasar. Sedangkan untuk langkah-langkah pembelajaran peer instruction flipped menurut Stelee (2016) adalah sebagai berikut:

a. Siswa menonton video pembelajaran di rumah.

Pada saat siswa menonton video pembelajaran di rumah, setiap siswa diminta juga untuk membuat suatu catatan kecil (ringkasan) dari apa yang siswa tangkap dari tayangan video pembelajaran yang dilihat. Selanjutnya membuat daftar pertanyaan jika terdapat hal-hal yang tidak dipahami terkait isi video yang diberikan.

b. Tes soal pertama yang mengajarkan konsep.

Setelah proses tanya jawab diawal pembelajaran, guru memberikan tes soal pertama mengenai suatu konsep dasar pada pembahasan yang akan dipelajari di kelas. Siswa diberikan waktu untuk mengerjakan soal secara individu.

c. Siswa saling berdiksusi dan saling berargumen terhadap tes soal pertama yang diberikan.

Pada tahap ini siswa diberikan kesempatan untuk menjelaskan jawaban dari tes soal pertama. Siswa meyakinkan temannya terhadap hasil yang diperoleh, Selanjutnya adalah pembentukan kelompok diskusi. Kelompok diskusi berdasarkan jawaban yang diberikan siswa. Siswa dikelompokkan secara heterogen yang terdiri dari siswa dengan jawaban tepat dan kurang 
tepat. Siswa dengan jawaban tepat atau benar akan cenderung mempertahankan dan menguatkan siswa dengan jawaban yang kurang tepat.

d. Tes soal kedua yang mengajarkan konsep atau menguatkan konsep.

Jika jawaban siswa yang benar lebih besar dari 80\% maka guru akan melanjutkan topik/soal kedua agar lebih menguatkan konsep yang telah didapat siswa. Begitu seterusnya, hingga jam pembelajaran berakhir.

e. Penilaian pemahaman siswa diakhir materi bab pembelajaran.

Diakhir pembahasan, siswa diberikan tes pemahaman yaitu soal evaluasi terhadap materi yang telah dipelajari.

Pemecahan masalah merupakan suatu proses untuk mengatasi kesulitan yang dihadapi untuk mencapai suatu tujuan yang ingin dicapai. Dalam memecahkan masalah matematis, diperlukan langkah-langkah konkrit yang benar sehingga jawaban yang diperoleh pun dapat menjadi benar. Ruseffendi (2006) mengemukakan bahwa dalam pemecahan masalah ada lima langkah yang harus dilakukan, yaitu: 1) menyajikan masalah dalam bentuk yang lebih jelas, 2) menyatakan masalah dalam bentuk yang operasional (dapat dipecahkan), 3) menyusun hipotesis-hipotesis alternatif dan prosedur kerja yang diperkirakan baik untuk dipergunakan dalam memecahkan masalah itu, 4) mengetes hipotesis dan melakukan kerja untuk memperoleh hasilnya (pengumpulan data, pengolahan data, dll); hasilnya mungkin lebih dari satu, 5) memeriksa kembali apakah hasil yang diperoleh itu benar; mungkin memilih pula pemecahan yang paling baik.

Kusumah (2008) menyatakan suatu masalah apalagi masalah non-rutin, arah penyelesaiannya belum jelas dan algoritma yang dapat digunakan mungkin belum ada. Pemecahan masalah sangat dibutuhkan dalam kehidupan sehari-hari. Matlin (Kusmaydi, 2011) menyatakan bahwa pemecahan masalah sangat dibutuhkan bilamana kita ingin mencapai tujuan tertentu tetapi cara penyelesaiannya tidak jelas.

NTCM (2000) menyatakan pemecahan masalah adalah jantung dari matematika. Keberhasilannya harus didukung oleh pengetahuan tentang materi matematika, strategi pemecahan masalah dan pengaturan untuk menyelesaikannya. Lebih lanjut NTCM (2000) juga menyatakan dalam pembelajaran matematika siswa diharapkan mampu: (1) membangun pengetahuan baru melalui pemecahan masalah; (2) memecahkan masalah matematika maupun dalam konteks lain; (3) menerapkan dan menggunakan berbagai strategi yang tepat untuk memecahkan masalah; (4) mengamati dan mereflesikan dalam proses pemecahan masalah matematika.

John Dewey (Nasution, 1987) mengemukakan langkah-langkah yang harus ditempuh dalam memecahkan masalah: (1) Pelajar dihadapkan dengan masalah, (2) Pelajar merumuskan masalah, (3) Pelajar merumuskan hipotesa, (4) Pelajar menguji hipotesa tersebut. Sedangkan langkah-langkah dalam memecahkan masalah, yang disarankan Polya (1973) terdiri dari empat langkah utama yaitu: Understanding the problem, Devising a Plan, Carrying out the Plan, dan Looking Back dengan rincian sebagai berikut:

1) Memahami masalah (Understanding the Problem) 
a. Problem apa yang dihadapi?

b. Apa yang diketahui?

c. Apa yang ditanya?

d. Apa kondisinya?

e. Bagaimana memilah kondisi-kondisi tersebut?

f. Tuliskan hal-hal itu, bila perlu buatlah gambar, gunakan simbol atau lambang yang sesuai.

2) Menyusun rencana pemecahannya (Devising a Plan)

Menemukan hubungan antara data dengan hal-hal yang belum diketahui, atau mengaitkan hal-hal yang mirip secara analogi dengan masalah. Proses ini diawali dengan proses pengenalan dan observasi kemudian dicari keteraturan dari pola masalah yang diberikan.

3) Melaksanakan rencana (Carrying out the Plan)

Menjalankan rencana guna menemukan solusi dapat dilakukan dengan cara:

a. Melaksanakan strategi sesuai dengan yang telah direncanakan pada tahap sebelumnya.

b. Melakukan pemeriksaan pada setiap langkah yang dikerjakan.

c. Mengupayakan agar pekerjaan dilakukan secara akurat.

4) Memeriksa kembali (Looking Back)

Melakukan pemeriksaan kembali terhadap solusi yang didapat dilakukan dalam beberapa kegiatan berikut:

a. Periksa hasil pada masalah asal.

b. Interpretasikan solusi pada masalah asal. Apakah solusi yang dihasilkan masuk akal?

c. Apakah ada cara lain untuk menyelesaikan masalah tersebut?

d. Jika memungkinkan, tentukan masalah lain yang berkaitan atau masalah lain yang lebih umum dimana strategi yang digunakan dapat bekerja.

Sumarmo (2010) menyatakan pemecahan masalah matematis mempunyai dua makna yaitu: a) Pemecahan masalah sebagai suatu pendekatan pembelajaran, yang digunakan untuk menemukan kembali (reinvention) dan memahami materi, konsep, dan prinsip matematika. Pembelajaran diawali dengan penyajian masalah atau situasi yang kontekstual kemudian melalui induksi siswa menemukan konsep/prinsip matematika dan b) pemecahan masalah sebagai kegiatan yang meliputi; (1) mengidentifikasi kecukupan data untuk pemecahan masalah; (2) membuat model matematik dari suatu situasi atau masalah sehari-hari dan menyelesaikannya; (3) memilih dan menerapkan strategi untuk menyelesaikan masalah matematika dan atau di luar matematika; (4) menjelaskan atau menginterpretasikan hasil sesuai permasalahan asal, serta memeriksa kebenaran hasil atau jawaban; (5) menerapkan matematika.

Hudojo (2002) menyatakan masalah matematis dapat dibagi dalam enam jenis, antara lain:

1. Masalah rutin, yaitu masalah yang prosedur penyelesaiannya sekedar mengulang, misalnya secara algoritmik.

2. Masalah non rutin, yaitu masalah yang prosedur penyelesaiannya memerlukan perencanaan penyelesaian, tidak sekedar menggunakan rumus, teorema atau dalil. 
3. Masalah rutin-terapan, yaitu masalah rutin yang dikaitkan dengan dunia nyata atau kehidupan sehari-hari, yang prosedur penyelesaiannya standar sebagaimana yang sudah diajarkan.

4. Masalah rutin non-terapan, yaitu masalah rutin yang lebih ke matematikanya daripada dikaitkan dengan dunia nyata atau kehidupan sehari-hari.

5. Masalah non-rutin terapan, yaitu masalah yang penyelesaiannya menuntut penyelesaian menurut perencanaan dengan mengaitkan dunia nyata atau kehidupan sehari-hari.

6. Masalah non rutin-non terapan, yaitu masalah yang berkaitan murni tentang hubungan matematis.

Indikator pemecahan masalah matematis yang dapat digunakan menurut Sumarmo (2008) adalah sebagai berikut:

1) Mengidentifikasi kecukupan data untuk pemecahan masalah,

2) Membuat model matematik dari suatu situasi atau masalah sehari-hari dan menyelesaikannya,

3) Memilih dan menerapkan strategi untuk menyelesaikan masalah matematika atau di luar matematika,

4) Menjelaskan atau menginterpretasikan hasil sesuai dengan permasalahan asal serta memeriksa kebenaran hasil jawaban,

5) Menerapkan matematika secara bermakna.

Berdasarkan latar belakang masalah maka rumusan masalah dalam penelitian ini adalah Adakah perbedaan peningkatan kemampuan pemecahan masalah matematis siswa antara siswa pra sejahtera yang menggunakan model pembelajaran flipped classroom tipe peer instruction flipped dengan siswa pra sejahtera yang memperoleh pembelajaran menggunakan konvensional? Sedangkan tujuan dari penelitian ini adalah untuk menelaah dan mendeskripsikan perbedaan peningkatan kemampuan pemecahan masalah matematis siswa antara siswa pra sejahtera yang menggunakan model pembelajaran flipped classroom tipe peer instruction flipped dengan siswa pra sejahtera yang memperoleh pembelajaran menggunakan konvensional.

\section{METODE PENELITIAN}

Penelitian ini bertujuan untuk menganalisis peningkatan kemampuan pemecahan masalah matematis dan self-efficacy siswa yang memperoleh pembelajaran Flipped Classroom tipe Peer Instruction Flipped. Berdasarkan tujuan penelitian, penelitian ini merupakan studi eksperimen dengan desain kelompok kontrol non-ekivalen yang merupakan bagian dari bentuk QuasiEksperimen, di mana subjek tidak dikelompokkan secara acak, tetapi menerima keadaan subjek apa adanya (Ruseffendi, 2005). Penelitian ini dilaksanakan di SMK Taruna Bangsa pada siswa kelas XI. Teknik pengambilan sampel yang digunakan dalam penelitian ini adalah dengan teknik purposive sampling, artinya pengambilan sampel dengan pertimbangan tertentu (Sugiyono, 2013). 
Pada desain ini terdapat pretes, perlakuan yang berbeda dan postes, dapat digambarkan sebagai berikut:

\begin{tabular}{lll}
$O$ & $X$ & $O$ \\
\hdashline & & $O$
\end{tabular}

Keterangan :

$\mathrm{O}:$ pretest $=$ posttest $($ tes kemampuan pemecahan masalah matematis)

$\mathrm{X}$ : Perlakuan pembelajaran dengan Flipped Classroom tipe Peer Instruction Flipped

------ :Subjek tidak dikelompokkan secara acak

Data-data yang diperoleh dari hasil pretes dan postes kemampuan pemecahan masalah matematis. Instrumen yang digunakan dalam penelitian ini adalah tes berupa soal-soal kemampuan pemecahan masalah matematis siswa. Adapun indikator dari aspek kemampuan pemecahan masalah matematis pada instrumen tes yang diujicobakan disajikan pada Tabel 31 berikut:

Tabel 1. Rubrik Skoring Tes Kemampuan Pemecahan masalah Matematis

\begin{tabular}{|c|c|c|c|c|}
\hline Skor & Memahami & $\begin{array}{l}\text { Membuat Rencana } \\
\text { Pemecahan }\end{array}$ & $\begin{array}{l}\text { Melakukan } \\
\text { perhituingan }\end{array}$ & $\begin{array}{l}\text { Memeriksa } \\
\text { kembali }\end{array}$ \\
\hline 0 & $\begin{array}{l}\text { Salah } \\
\text { menginterpretasi } \\
\text { atau salah sama } \\
\text { sekali } \\
\end{array}$ & $\begin{array}{l}\text { Tidak ada rencana } \\
\text { atau membuat rencana } \\
\text { yang } \\
\text { tidak relevan }\end{array}$ & $\begin{array}{l}\text { Tidak melakukan } \\
\text { perhitungan }\end{array}$ & $\begin{array}{l}\text { Tidak ada } \\
\text { pemeriksaan } \\
\text { atau keterangan } \\
\text { lain }\end{array}$ \\
\hline 1 & $\begin{array}{l}\text { Salah } \\
\text { menginterpretasi } \\
\text { sebagian soal dan } \\
\text { mengabaikan } \\
\text { kondisi soal }\end{array}$ & $\begin{array}{l}\text { Membuat rencana } \\
\text { pemecahan yang tidak } \\
\text { dapat dilaksanakan, } \\
\text { sehingga tidak dapat } \\
\text { dilaksanakan }\end{array}$ & $\begin{array}{l}\text { Melaksanakan } \\
\text { prosedur yang } \\
\text { benar dan } \\
\text { mungkin } \\
\text { menghasilkan } \\
\text { jawaban yang } \\
\text { benar tetapi salah } \\
\text { perhitungan }\end{array}$ & $\begin{array}{l}\text { Ada } \\
\text { pemeriksaan } \\
\text { tetapi tidak } \\
\text { tuntas }\end{array}$ \\
\hline 2 & $\begin{array}{l}\text { Memahami } \\
\text { masalah soal } \\
\text { selengkapnya }\end{array}$ & $\begin{array}{l}\text { Membuat rencana } \\
\text { yang benar tetapi } \\
\text { salah dalam hasil atau } \\
\text { tidak ada hasilnya }\end{array}$ & $\begin{array}{l}\text { Melakukan proses } \\
\text { yang benar dan } \\
\text { mendapatkan hasil } \\
\text { yang benar }\end{array}$ & $\begin{array}{l}\text { Pemeriksaan } \\
\text { dilakukan } \\
\text { untuk melihat } \\
\text { kebenaran } \\
\text { proses } \\
\end{array}$ \\
\hline 3 & & $\begin{array}{l}\text { Membuat rencana } \\
\text { benar tetapi belum } \\
\text { lengkap }\end{array}$ & & \\
\hline 4 & & $\begin{array}{l}\text { Membuat rencana } \\
\text { sesuai dengan } \\
\text { prosedure dan } \\
\text { mengarah pada solusi } \\
\text { yang benar }\end{array}$ & & \\
\hline Skor & 2 & 4 & 2 & 2 \\
\hline
\end{tabular}


Teknik pengumpulan data dalam penelitian ini berupa tes uraian untuk mengukur peningkatan kemampuan pemecahan masalah matematis siswa. Analisis data dilakukan terhadap rataan gain ternormalisasi kedua kelompok sampel dengan menggunakan uji perbedaan rataan gain ternormalisasi untuk melihat perbedaan peningkatan kemampuan pemecahan masalah matematis. Data yang diperoleh dari hasil tes diolah melalui tahap-tahap sebagai berikut:

a. Memberikan skor jawaban siswa sesuai dengan kunci jawaban dan sistem penskoran yang digunakan.

b. Membuat tabel skor pretes dan postes siswa kelas yang memperoleh pembelajaran Flipped Classroom tipe Peer Instruction Flipped dan kelas yang memperoleh pembelajaran secara konvensional.

c. Menghitung peningkatan kemampuan yang terjadi pada siswa kelompok atas dan siswa kelompok bawah dengan rumus $\mathrm{N}$-Gain ternormalisasi, yaitu:

$\mathrm{N}$-Gain ternormalisasi $(\mathrm{g})=\frac{\text { skor postes-skor pretes }}{\text { skor ideal-skor pretes }} \quad$ (Meltzer,2002)

Hasil perhitungan N-Gain kemudian diinterpretasikan dengan menggunakan klasifikasi N-Gain ternormalisasi (Hake, 2002), disajikan pada Tabel 2 berikut:

Tabel 2. Klasifikasi N-Gain Ternormalisasi (g)

\begin{tabular}{cc}
\hline $\begin{array}{c}\text { Besarnya N-Gain } \\
(\mathbf{g})\end{array}$ & Interpretasi \\
\hline $\mathrm{g} \geq 0,7$ & Tinggi \\
\hline $0,3 \leq \mathrm{g}<0,7$ & Sedang \\
\hline $\mathrm{g}<0,3$ & Rendah \\
\hline
\end{tabular}

Perhitungan N-Gain ternormalisasi dilakukan karena penelitian ini tidak hanya melihat peningkatan siswa tetapi juga melihat kualitas dari peningkatan tersebut.

d. Melakukan uji normalitas untuk mengetahui kenormalan data skor pretes dan skor N-Gain kemampuan pemecahan masalah matematis menggunakan uji statistik One-Sample Kolmogorov-Smirnov.

e. Menguji homogenitas varians tes kemampuan pemecahan masalah matematis menggunakan uji Homogeneity of Variance (Levene Statistic).

f. Jika sebaran data normal dan homogen, akan dilakukan uji kesamaan rataan skor pretes dan perbedaan rataan skor N-Gain menggunakan Compare Mean (Independent-Samples T-Test).

\section{HASIL PENELITIAN DAN PEMBAHASAN}

\section{Hasil Pretes Kemampuan Pemecahan masalah matematis}

Untuk mengetahui bahwa ada perbedaan atau tidak ada perbedaan kemampuan awal pemecahan masalah matematis pada kelas yang memperoleh Flipped Classroom tipe Peer Instruction Flipped dan kelas yang memperoleh 
pembelajaran Konvensional dilakukan uji kesamaan rataan. Terlebih dahulu dilakukan uji normalitas dan uji homogenitas, sebagai persyaratan dalam menentukan uji statistik yang harus digunakan.

\section{Uji Normalitas Skor Pretes}

Hipotesis uji normalitas skor pretes kemampuan pemecahan masalah matematis kelas yang memperoleh pembelajaran Flipped Classroom tipe Peer Instruction Flipped dan kelas yang memperoleh pembelajaran konvensional adalah:

$\mathrm{H}_{0} \quad$ : Data berdistribusi normal

$\mathrm{H}_{1} \quad$ : Data tidak berdistribusi normal

Uji normalitas skor pretes dihitung dengan menggunakan SPSS 16. Hasil uji normalitas disajikan pada Tabel 3.

Tabel 3. Uji Normalitas Skor Pretes Kemampuan Pemecahan masalah matematis

\begin{tabular}{llccc}
\hline & & \multicolumn{3}{c}{ Kolmogorov-Smirnov $^{\mathrm{a}}$} \\
\cline { 3 - 5 } & KELOMPOK & Statistic & $\mathrm{df}$ & \multicolumn{1}{c}{ Sig. } \\
\hline PRETE & EKSPERIME & .157 & 19 & $.200^{*}$ \\
$\mathrm{~S}$ & $\mathrm{~N}$ & & & \\
& KONTROL & .208 & 19 & .030 \\
\hline
\end{tabular}

Dari Tabel 3, terlihat bahwa nilai signifikansi uji Kolmogorov Smirnov pada skor pretes kemampuan pemecahan masalah matematis yang memperoleh pembelajaran Flipped Classroom tipe Peer Instruction Flipped yaitu 0,200 atau berdistribusi normal sedangkan untuk skor pretes kemampuan pemecahan masalah matematis kelas yang memperoleh pembelajaran menggunakan Konvensional yaitu 0,030 atau tidak berdistribusi normal. Karena salah satu kelas mempunyai nilai signifikansi kurang dari 0,05, maka disimpulkan bahwa data pretes berdistribusi tidak normal. Karena data pretes tidak berdistribusi normal, maka pengujian selanjutnya adalah uji non parametrik.

\section{Uji Kesamaan Rataan Skor Pretes}

Uji kesamaan rataan dilakukan untuk mengetahui bahwa tidak terdapat perbedaan kemampuan awal kelas yang memperoleh pembelajaran Flipped Classroom tipe Peer Instruction Flipped dan kelas yang memperoleh pembelajaran menggunakan konvensioal. Berdasarkan uji normalitas yang telah dilakukan terhadap kedua kelompok data skor pretes kemampuan pemecahan masalah matematis kelas yang memperoleh pembelajaran Flipped Classroom tipe Peer Instruction Flipped dan kelas yang memperoleh pembelajaran menggunakan konvensional, dinyatakan bahwa salah satu kelas tidak berditribusi normal, maka untuk mengetahui signifikansi kesamaan rataan kedua kelompok menggunakan statistik non-parametrik (Uji Mann-Whitney). Rumusan hipotesis uji kesamaan rataan kemampuan pemecahan masalah matematis adalah 
$\mathrm{H}_{0}$ : Tidak terdapat perbedaan rataan skor pretes kemampuan pemecahan masalah matematis siswa antara kelas yang memperoleh pembelajaran Flipped Classroom tipe Peer Instruction Flipped dan kelas yang memperoleh pembelajaran menggunakan konvensional.

$\mathrm{H}_{1}$ : Terdapat perbedaan rataan skor pretes kemampuan pemecahan masalah matematis siswa antara kelas yang memperoleh pembelajaran Flipped Classroom tipe Peer Instruction Flipped dan kelas yang memperoleh pembelajaran menggunakan konvensional.

Hasil uji kesamaan rataan menggunakan SPSS disajikan pada Tabel 4.

Tabel 4. Uji Kesamaan Skor Pretes Kemampuan Pemecahan Masalah Matematis

\begin{tabular}{lr}
\hline & NILAI \\
\hline Mann-Whitney U & 127.500 \\
Wilcoxon W & 317.500 \\
Z & -1.562 \\
Asymp. Sig. (2-tailed) & .118 \\
Exact Sig. [2*(1-tailed & $.123^{\text {a }}$ \\
Sig.)] & \\
\hline
\end{tabular}

Dari Tabel 4 dapat dilihat bahwa nilai Asymp. sig. (2.tailed) adlah 0,118 > $\alpha=0,05$. Hal ini menunjukkan bahwa $\mathrm{H}_{0}$ diterima, artinya tidak terdapat perbedaan antara skor pretes kemampuan pemecahan masalah matematis kelas yang memperoleh pembelajaran Flipped Classroom tipe Peer Instruction Flipped dan kelas yang memperoleh pembelajaran menggunakan konvensional, dengan kata lain kedua kelas memiliki kemampuan awal yang sama pada kemampuan pemecahan masalah matematis.

\section{Peningkatan kemampuan pemahan matematis}

Secara umum terjadi peningkatan skor pretes dan skor postes, untuk melihat peningkatan kemampuan pemecahan masalah matematis yang dicapai oleh siswa digunakan data N-Gain ternormalisasi dan untuk mengetahui apakah peningkatan kemampuan pemecahan masalah matematis siswa kelas yang memperoleh pembelajaran Flipped Classroom tipe Peer Instruction Flipped lebih baik daripada kelas yang memperoleh pembelajaran menggunakan konvensional, perlu dilakukan pengujian perbedaan rataan. Sebelumnya dilakukan uji normalitas dan uji homogenitas terhadap skor N-Gain kedua kelas.

\section{Uji Normalitas Skor N-Gain}

Hipotesis uji normalitas skor N-Gain kemampuan pemecahan masalah matematis kelas yang memperoleh pembelajaran Flipped Classroom tipe Peer 
Instruction Flipped dan kelas yang memperoleh pembelajaran menggunakan konvensional adalah:

$\mathrm{H}_{0}$ : Data berdistribusi normal

$\mathrm{H}_{1}$ : Data tidak berdistribusi normal

Uji normalitas skor N-Gain dihitung dengan menggunakan SPSS. Hasil uji normalitas disajikan pada Tabel 5 .

Tabel 5. Uji Normalitas N-Gain Kemampuan Pemecahan masalah

\begin{tabular}{llccc}
\hline & & \multicolumn{3}{c}{ Kolmogorov-Smirnov $^{\mathrm{a}}$} \\
\cline { 3 - 5 } & KELOMPOK & Statistic & $\mathrm{df}$ & \multicolumn{1}{c}{ Sig. } \\
\hline N- & ESKPERIME & .173 & 18 & .160 \\
GAIN & $\mathrm{N}$ & & & \\
& KONTROL & .158 & 20 & $.200^{*}$ \\
\hline
\end{tabular}

Dari Tabel 5, terlihat bahwa nilai signifikansi uji Kolmogorov Smirnov pada skor pretes kemampuan pemecahan masalah matematis yang memperoleh pembelajaran Flipped Classroom tipe Peer Instruction Flipped yaitu 0,160 atau berdistribusi normal sedangkan untuk skor pretes kemampuan pemecahan masalah matematis kelas yang memperoleh pembelajaran menggunakan Konvensional yaitu 0,200 atau berdistribusi normal. Kedua kelas berdistribusi normal artinya data skor N-Gain kemampuan pemecahan masalah matematis siswa berdistribusi normal.

\section{Uji Homogenitas Skor N-Gain}

Hipotesis uji homogenitas skor N-Gain kemampuan pemecahan masalah matematis siswa kelas yang memperoleh pembelajaran Flipped Classroom tipe Peer Instruction Flipped dan kelas yang memperoleh pembelajaran menggunakan Konvensional adalah:

$\mathrm{H}_{0}$ : varians skor $\mathrm{N}-$ Gain kemampuan pemecahan masalah matematis kedua kelas homogen

$\mathrm{H}_{1}$ : varians skor $\mathrm{N}$-Gain kemampuan pemecahan masalah matematis kedua kelas tidak homogen

Uji Homogenitas skor N-Gain dihitung dengan menggunakan SPSS 16. Hasil uji homogenitas disajikan pada Tabel 6.

Tabel 6. Uji Homogenitas N-Gain Kemampuan Pemecahan masalah matematis

\begin{tabular}{cccc}
\hline $\begin{array}{l}\text { Levene } \\
\text { Statistic }\end{array}$ & df1 & df2 & Sig. \\
\hline 2.435 & 1 & 36 & .127 \\
\hline
\end{tabular}

Dari Tabel 6 terlihat bahwa nilai signifikansi 0,127. Nilai signifikansi tersebut lebih besar dari taraf signifikansi $(\alpha)$ 0,05 maka $\mathrm{H}_{0}$ diterima, sehingga 
dapat disimpulkan bahwa kedua kelompok data skor N-Gain kemampuan pemecahan masalah matematis ini memiliki varians yang homogen.

\section{Uji Perbedaan Rataan Skor N-Gain dalam Rangka Menguji Hipotesis}

Berdasarkan uji normalitas dan homogenitas yang telah dilakukan terhadap skor N-Gain kemampuan pemecahan masalah matematis kelas yang memperoleh pembelajaran Flipped Classroom tipe Peer Instruction Flipped dan kelas yang memperoleh pembelajaran menggunakan konvensional, dinyatakan bahwa skor $\mathrm{N}$-Gain kedua kelas berdistribusi normal dan mempunyai varians yang homogen, maka untuk mengetahui perbedaan rataan kedua kelas digunakan uji statistik Compare Mean (Independent-Samples T-Test). Hipotesis yang diajukan adalah peningkatan kemampuan pemecahan masalah matematis siswa yang memperoleh pembelajaran Flipped Classroom tipe Peer Instruction Flipped lebih baik daripada peningkatan kemampuan pemecahan masalah matematis siswa yang memperoleh pembelajaran menggunakan konvensional. Hipotesis penelitian yang diuji adalah perbedaan peningkatan kemampuan pemecahan masalah matematis siswa antara siswa pra sejahtera yang menggunakan model pembelajaran flipped classroom tipe peer instruction flipped dengan siswa pra sejahtera yang memperoleh pembelajaran menggunakan konvensional.

$\mathrm{H}_{0}$ : Tidak terdapat perbedaan peningkatan kemampuan pemecahan masalah matematis siswa antara siswa pra sejahtera yang menggunakan model pembelajaran flipped classroom tipe peer instruction flipped dengan siswa pra sejahtera yang memperoleh pembelajaran menggunakan konvensional

$\mathrm{H}_{1}$ : Terdapat perbedaan peningkatan kemampuan pemecahan masalah matematis siswa antara siswa pra sejahtera yang menggunakan model pembelajaran flipped classroom tipe peer instruction flipped dengan siswa pra sejahtera yang memperoleh pembelajaran menggunakan konvensional

Tabel 7. Uji Perbedaan N-Gain Kemampuan Pemecahan masalah matematis

\begin{tabular}{lllll}
\hline & $\mathrm{t}$ & $\mathrm{df}$ & Sig. (2-tailed) \\
\hline NILAI & & \\
$\begin{array}{l}\text { Equal variances assumed } \\
\begin{array}{l}\text { Equal variances not } \\
\text { assumed }\end{array}\end{array}$ & 3.141 & 32.187 & .004 & \\
\end{tabular}

Tabel 7 terlihat bahwa nilai signifikansi 0,004. Nilai signifikansi tersebut lebih kecil dari taraf signifikansi $(\alpha)$ 0,05 maka hal ini menunjukkan bahwa $\mathrm{H}_{0}$ ditolak dan $\mathrm{H}_{1}$ diterima, artinya terdapat perbedaan peningkatan kemampuan pemecahan masalah matematis siswa antara siswa pra sejahtera yang menggunakan model pembelajaran flipped classroom tipe peer instruction flipped dengan siswa pra sejahtera yang memperoleh pembelajaran menggunakan konvensional. 


\section{SIMPULAN DAN SARAN \\ Simpulan}

Berdasarkan hasil penelitian dan pembahasan mengenai peningkatan kemampuan pemecahan masalah matematis siswa pra sejahtera, antara yang memperoleh pembelajaran dengan Flipped Classroom Tipe Peer Instruction Flipped dan yang mendapatkan pembelajaran menggunakan konvensional diperoleh simpulan bahwa terdapat perbedaan peningkatan kemampuan pemecahan masalah matematis siswa antara siswa pra sejahtera yang menggunakan model pembelajaran flipped classroom tipe peer instruction flipped dengan siswa pra sejahtera yang memperoleh pembelajaran menggunakan konvensional.

\section{Saran}

Berdasarkan hasil temuan yang diperoleh pada penelitian ini, saran yang dapat disampaikan sebagai berikut:

1. Pembelajaran menggunakan pendekatan Flipped Classroom Tipe Peer Instruction Flipped dapat dijadikan salah satu alternatif pembelajaran matematika, terutama untuk meningkatkan kemampuan pemecahan masalah matematis.

2. Pengajar harus lebih memotivasi siswa agar berperan aktif dalam proses pembelajaran serta lebih kreatif dalam membuat video materi bahan ajar.

\section{DAFTAR PUSTAKA}

Bergmann, Jonathan and Aaron Sams. (2012). Flip Your Classroom : Reach Every Student in Every Class Every Day. United States : The International Society For Technology In Education.

Carl R., dkk. (2017). The Flipped Classroom Practice and Practices in Higher Educations. Singapore: Springer Nature Singapore.

Departemen Pendidikan Nasional. (2006). Kurikulum Tingkat Satuan Pendidikan. Jakarta: Pusat Kurikulum Balitbang Depdiknas.

Fulton, Kathleen P. (2012). 10 reasons to flip, The Phi Delta Kappan, Vol. 94, No.2 (October 2012), pp. 20-24.

Gunyou, John. (2015). I Flipped My Classroom: One Teacher's Quest to Remain Relevant, Journal of Public Affairs Education, Vol. 21, No. 1 (WINTER 2015), pp. 13-24.Mazur, Eric. (1997). Peer Instruction: A User's Manual. New Jersey : Prentice Hall.

Hake, R.R. (2002). Relationship of Individual Student Normalized Learning Gains In Mechanics With Gender, High-School Physics, and Pretest Scores on Mathematics and Spatial Visualization. Department of Physics, Indiana University. Submit to the Physics Education Research Conference; Boise, Idaho; August 2002. [Online]. Tersedia: http://www.arxiv.org and also as ref. 22 at www.physics.indiana.edu/ hake/

Hudojo, H. (2002). Representasi Belajar Berbasis Masalah. Prosiding Konferensi Nasional Matematika XI, Edisi Khusus.

Hudojo, H. (2003). Pengembangan Kurikulum dan Pembelajaran Matematika. Malang: Universitas Negeri Malang. 
Kusumah, Y. S. (2008). Konsep, Pengembangan, dan Implementasi ComputerBased Learning dalam Peningkatan Kemampuan HighOrderMathematical Thinking. Pidato pengukuhan Guru Besar dalamPendidikan Matematika Universitas Pendidikan Indonesia tanggal 23 Oktober 2008. Bandung: UPI PRESS.

Meltzer, D.E (2002). The Relationship between mathemathics Preparation and Conceptual Leaarning Gain in Physics: A Possible "Hidden Variabel" in Diagnostics Pretest Scores. In American Journal of Physics. [Online]. Vol. $\quad 70 . \quad$ Page (12) 1259-1268. Tersedia: http://www.physics.iastate.edu/per/docs/AJP-Des-2002-Vol.70-12591268.pdf. [15 Maret 2019]

Nasution, S. (1987). Berbagai Pendekatan dalam Proses Belajar Mengajar. Jakarta: Bina Aksara.

National Council of Teachers of Mathematics. (2000). Principles and Standards for School Mathematics. Reston, VA: NCTM.

Polya, G. (1973). How to Solve It, a New Aspect of Mathematical Method. New Jersey: Princeton University Press.

Ruseffendi, E.T. (2005). Dasar-dasar Penelitian Pendidikan dan Bidang Noneksakta Lainnya.. Bandung: Tarsito.

Ruseffendi, E.T. (2006). Pengantar Kepada Membantu Guru Mengembangkan Kompetensinya Dalam Pengajaran Matematika Untuk Meningkatkan $C B S A$. Bandung:tarsito.

Stelee, Kevin M. The Flipped Classroom : Cuting-Edge, Practical Strategies to Succesfully "Flip" Your Classroom,, 2016, h. 2, (http://www.kevinmsteele.com/ the_flipped_classroom_-_ice.pdf)

Sugiyono. (2013). Metode Penelitian Pendidikan (Pendekatan Kuantitatif, Kualitatif dan $R \& D)$ ). Bandung: Alfabeta.

Sumarmo, U. (2010). Pendidikan Karakter, Berpikir dan Disposisi Logis, Kritis, dan Kreatif dalam Pembelajaran Matematika. Makalah pada perkuliahan Evaluasi Matematika 2011 SPS UPI: Tidak Diterbitkan.

Wardhani, S. (2010). Implikasi Karakteristik Matematika dalam Pencapaian Tujuan Mata Pelajaran Matematika di SMP/MTs. Yogyakarta: Depdiknas PPPPTK. 